\title{
Musik bukan Pekerjaan: Distingsi dan Transgresi dalam Karier Bermusik Musisi Metal Ekstrem Yogyakarta
}

\author{
Agustinus Aryo Lukisworo $^{1} \&$ Oki Rahadianto Sutopo ${ }^{2}$ \\ ${ }^{1}$ Program Studi Sosiologi FISIP UAJY, ${ }^{2}$ Departemen Sosiologi FISIPOL UGM \\ agustinusaryo@gmail.com | oki.rahadianto@ugm.ac.id
}

\begin{abstract}
This article focuses on the separation between music and work that has been done by extreme metal musicians in Yogyakarta. Besides providing a deeper explanation of youth cultural practices in Yogyakarta, this article also fills the gap between youth culture and youth transition perspective. This article uses a qualitative ethnographic approach which has been done through six months of data collecting. This research approach was chosen to capture the concrete reality that has been experienced by informants. Based on the findings, the separation between music and work among informants, on the one hand, could be understood as a strategy to maintain informants' pride within the extreme metal scene. On the other hand, this separation also could be defined as a strategy to maintain informants' social position, especially as the representation of Indonesian middle class.
\end{abstract}

Keywords: Youth Culture | Youth Transition | Extreme Metal Music | Work | Strategy

\section{PENDAHULUAN}

Dalam artikel yang berjudul "Youth, Music, and DIY Careers", Andy Bennett (2018) menjelaskan mengenai munculnya perubahan pola kaum muda dalam melalui proses transisi menuju pekerjaan di beberapa negara maju. Hal ini direpresentasikan dengan munculnya pengelolaan karier bermusik independen secara lebih serius dan cenderung profesional, serta oleh konversi karier bermusik tersebut -yang awalnya dimaknai sebagai hobi- menjadi sebuah pekerjaan yang memiliki implikasi ekonomis. Secara struktural, hal ini dijelaskan sebagai dampak dari perlambatan perkembangan ekonomi yang berimplikasi pada penurunan kesempatan kerja secara formal, khususnya bagi kaum muda. Akan tetapi, penjelasan dari realitas tersebut ternyata tidak hanya berhenti pada persoalan struktural saja, namun juga menyangkut dimensi ide atau aspek kultural dari para pelaku. Alih-alih berpikir mengenai kemapanan, para pelaku skena musik independen/DIY (do-ityourself) justru menekankan pentingnya kebebasan berekspresi dan komitmen pada hal-hal yang disenangi, dalam hal ini musik. Karena itu, konversi musik menjadi pekerjaan tetap dilakukan, meski tidak selalu menjanjikan pendapatan ekonomi yang memadai, dan bahkan lebih sering beririsan dengan gaya hidup yang rentan secara ekonomi.

Terkait dengan hal ini, penulis menjumpai realitas yang 'serupa tapi tak sama' di dalam skena metal ekstrem Yogyakarta, khususnya dalam kasus 
komunitas 666. Dikatakan serupa karena pengelolaan karier bermusik para musisi metal ekstrem yang tergabung komunitas 666 tergolong profesional (Dummond, 1990). Dalam hal ini, praktik yang dilakukan oleh musisi komunitas 666 tidak hanya sekedar berorientasi menjadi cover band, namun sudah terarah pada produksi album secara mandiri. Kemudian terkait proses produksi album, didukung dengan peralatan yang layak - mulai dari alat musik yang dimiliki secara pribadi dan juga peralatan seperti amplifier, komputer dan mixer - serta tenaga operator profesional untuk menangani proses mixing dan mastering. Kemudian proses produksi tersebut ditopang dengan proses distribusi secara luas, yang ditempuh band-band komunitas 666 melalui kerjasama dengan beberapa label rekaman metal ekstrem independen di beberapa kota dan negara lain, seperti Jakarta, Bandung, Malaysia, Rusia, dan Jerman. Selain itu, terdapat juga aktivitas promosional yang dilakukan melalui tour, baik di kota-kota di Indonesia, seperti Surabaya, Cirebon, Batu, Bandung, dan Jakarta, maupun di beberapa negara seperti Malaysia, Singapura, dan Jepang.

Namun demikian, praktik dan karier bermusik tersebut tidak dapat dimaknai dengan cara yang sama. Hal ini disebabkan oleh tidak adanya musisi komunitas 666 yang memposisikan karier bermusik mereka sebagai pekerjaan. Meski memiliki karakteristik pekerjaan yang beragam, para musisi komunitas 666 yang mayoritas saat ini berada dalam usia akhir 20-an memilih untuk bekerja secara full-time. Dengan kata lain, para musisi komunitas 666 tetap melalui proses transisi menuju dunia kerja secara konvensional. Beberapa di antara musisi komunitas 666 bekerja dalam pekerjaan formal, baik dalam lembaga publik seperti lembaga kenegaraan, maupun lembaga privat seperti media massa dan perusahaan mobile game. Bahkan beberapa di antaranya melakukan mobilitas permanen ke Jakarta untuk memperoleh pekerjaan. Sementara sebagian yang lain memutuskan tetap tinggal di Yogyakarta dan bekerja dalam sektor non formal, namun dengan beban kerja dan penghasilan yang relatif setara dengan pekerjaan formal. Meski terdapat salah satu musisi yang berprofesi sebagai artworker, sebuah bidang pekerjaan yang berkaitan dengan skena metal ekstrem, namun aktivitas bermusik tetap tidak dilakukan dalam konteks bekerja.

Gap realitas inilah yang kemudian melandasi dan akan dibahas dalam tulisan ini. Secara empiris, para musisi komunitas 666 yang tinggal di Indonesia memiliki konteks daur hidup yang sama dengan para pelaku skena musik di beberapa negara maju yakni harus melalui proses transisi ketika peluang kerja dalam ranah formal menjadi terbatas (Bennett, 2018; Sutopo, 2013). Namun ternyata kesamaan konteks tersebut tidak serta merta melahirkan tindakan yang serupa. Hal ini direpresentasikan oleh tindakan para musisi metal ekstrem Indonesia yang lebih memilih menghadapi kebaruan tantangan transisi di era kontemporer dengan cara yang konvensional melalui pekerjaan full time, dan tetap menjaga karier bermusik dalam koridor profesional-amatir (Quader, 2013). Kemudian secara teoritis, meski gap realitas tersebut dapat dengan mudah diartikan sebagai produk dari simbol resistensi kaum muda terhadap struktur dan mekanisme sosial yang berlaku dalam masyarakat, sebagaimana terjadi di Inggris pasca Perang Dunia ke-2 (Hall dan Jefferson, 1976; Hebdige, 1979), namun pemaknaan semacam ini terlalu spekulatif dan terlalu banyak mereduksi suara pelaku, sehingga tidak lagi mumpuni untuk memberikan penjelasan atas realitas budaya kaum muda. Kritik ini diperkuat dengan temuan beberapa literatur yang menjelaskan bahwa praktik budaya kaum muda kontemporer tidak selalu berkaitan dengan realitas makro struktural, seperti kondisi ekonomi-politik, namun justru lebih berkaitan dengan persoalan-persoalan mikro, seperti identitas dan distingsi sosial (Muggleton, 2000; Wallach, 2008; Ferreira, 2016, Bennett, 2018). 
Berdasarkan paparan tersebut, tulisan ini akan berfokus pada praktik pemisahan antara karir bermusik dan pekerjaan oleh para musisi metal ekstrem komunitas 666. Dalam hal ini, praktik tersebut dipahami sebagai produk dari cara pandang yang berkembang di antara musisi komunitas 666. Karena itu, tulisan ini akan mendalami sisi ide dari para musisi komunitas 666, khususnya mengenai makna dari "musik metal ekstrem" dan "pekerjaan". Selain bertujuan untuk membangun pemahaman kontekstual mengenai praktik budaya kaum muda dalam skena metal ekstrem, serta keterkaitannya dengan transisi para pelaku, penentuan fokus tersebut juga dilandasi tujuan teoritis berupa upaya membangun jembatan penghubung antara perspektif budaya dengan perspektif transisi kaum muda.

\section{Studi-Studi Terdahulu}

Studi mengenai metal ekstrem di Indonesia, sudah dilakukan oleh beberapa peneliti, baik yang berasal dari luar maupun dari Indonesia. Beberapa di antaranya memberikan pemaparan mengenai komunitas-komunitas musik metal ekstrem di Indonesia pada era 1990-an (Baulch, 2003; Wallach, 2005; 2008). Melalui studistudi tersebut, dapat dipahami bahwa skena metal ekstrem merupakan entitas yang didominasi oleh nilai-nilai kolektivitas dan solidaritas kaum muda, khususnya yang berasal dari kelas menengah. Selain itu, beberapa studi tersebut juga menunjukkan adanya ambivalensi makna praktik bermusik metal ekstrem, yang bergerak di antara distingsi sosial dan resistensi politik terhadap negara.

Namun dengan fokus pada realitasrealitas makro, beberapa penelitian mengenai skena metal ekstrem di Indonesia era 1990-an tersebut cenderung melihat skena metal ekstrem sebagai entitas tunggal. Meski interpretasi yang dihasilkan tidak sepenuhnya salah, dalam perkembangan selanjutnya muncul beberapa penelitian lain yang melihat skena metal ekstrem di Indonesia sebagai sebuah struktur yang terdiri dari keragaman unsur. Misalnya dalam penelitian James \& Walsch (2018) yang memberikan pemaparan mengenai kontestasi ide antara Islamisme dengan sekularisme dalam skena metal ekstrem di Indonesia. Meski tidak berujung pada separasi secara tegas, namun setidaknya hal ini menjadi penanda awal perkembangan konstruk berpikir mengenai skena metal ekstrem Indonesia sebagai entitas yang tidak hanya terdiri dari habitus atau sistem ide tunggal.

Selain itu, pluralitas ide dalam skena metal ekstrem juga tampak dari penjelasan Lukisworo \& Sutopo (2017) mengenai perbedaan cara pandang antar pelaku skena metal ekstrem, khususnya para musisi, yang berimplikasi pada perbedaan etika penyajian (live performance) musik. Secara praktis, hal ini berkaitan dengan pemaknaan panggung musik umum non komunitas. Walaupun di satu sisi dapat dipandang sebagai ruang apresiasi, di sisi yang lain dapat dipandang sebagai ruang yang tidak tepat untuk menyajikan musik metal ekstrem. Lebih lanjut, dalam artikel Sutopo, Wibawanto, \& Lukisworo (2020) dijelaskan bahwa totalitas serta aspirasi karir bermusik dari para musisi DIY cenderung beragam. Adapun keragaman ini dilandasi oleh perbedaan keterlekatan serta pengalaman bermusik yang dimiliki oleh para musisi.

Terkait dengan proses pemilihan pekerjaan, Sutopo (2011) menjelaskan bahwa karakteristik transisi kaum muda di Indonesia tidak berlangsung secara otonom. Hal ini direpresentasikan oleh besarnya peran orang tua dalam proses pemilihan karir pekerjaan. Bahkan, memilih pekerjaan dalam ranah non konvensional, misalnya sebagai musisi, masih cenderung dinilai menjadi suatu keputusan yang tidak layak. Karena itu, dalam beberapa kasus, proses pemilihan pekerjaan menjadi musisi sering dilandasi oleh perdebatan dan negosiasi yang panjang antara kaum muda dan orang tua. 
Namun hal ini ternyata hanya menjadi salah satu tantangan yang dihadapi oleh kaum muda saja, khususnya yang hendak berkarir menjadi musisi. Karena selain persoalan perbedaan pendapat dengan orang tua, masih terdapat persoalan lain, yakni hierarkisitas skena musik serta dominasi musisi senior (Sutopo \& Nilan, 2018). Hal ini kemudian menimbulkan tuntutan individu untuk dapat mengakumulasikan modal yang tepat, untuk dapat mengembangkan karier. Lebih lanjut, hierarkisitas skena juga berlaku dalam skena metal ekstrem. Hal ini sebagaimana dijelaskan oleh Sutopo \& Lukisworo (2020) melalui pemaparan berbagai bentuk modal yang berlaku di dalam skena metal ekstrem, seperti referensi musik, rekognisi, dan juga kemampuan teknis. Kemudian untuk dapat mengakumulasikan, mengoperasikan dan juga mengelola berbagai modal tersebut, diperlukan beberapa nilai yang perlu diinternalisasikan oleh para musisi, yakni otentisitas, kemandirian, dan komunitas.

\section{METODE PENELITIAN}

Penelitian ini menggunakan pendekatan kualitatif etnografis, dengan tujuan agar dapat membangun kebenaran dari 'bawah', sesuai dengan realitas alamiah konkret yang dialami para informan. Etnografi juga memberikan peluang kepada peneliti untuk dapat membangun pengalaman langsung (first hand experience) (Bennett, 2002; 2003) atas realitas praktik bermusik para informan dalam skena metal ekstrem. Adapun proses pengumpulan data dalam penelitian ini, dilakukan selama enam bulan, mulai dari bulan Januari hingga Agustus 2019. Selain melalui observasi pada beberapa lokasi, seperti studio, rumah, dan tempat nongkrong para informan, proses pengumpulan data juga dilakukan melalui proses wawancara mendalam semi terstruktur dengan karakteristik pertanyaan open ended.
Subjek yang dibahas dalam artikel ini ditentukan secara purposive, yakni komunitas 666. Komunitas ini merupakan salah satu entitas dalam skena metal ekstrem Yogyakarta yang mulai terbentuk pada tahun 2012 oleh beberapa musisi metal ekstrem. Dengan kata lain, komunitas 666 diposisikan sebagai bagian, alih-alih representasi, dari skena metal ekstrem Yogyakarta secara keseluruhan. Nama "komunitas 666" bukan sebuah nama yang diproklamirkan secara 'resmi', namun diambil peneliti dari grup chat aplikasi "Whatsapp" yang terdiri dari para musisi komunitas 666. Seluruh musisi metal ekstrem komunitas 666 yang berlatar belakang kelas menengah, mulai aktif membangun karier bermusik pada era pasca Orde Baru, tepatnya pada pertengahan hingga akhir era 2000-an.

Terkait dengan subjek penelitian tersebut, komunitas 666 dipilih untuk memperoleh gambaran realitas praktik bermusik yang diawali dalam konteks pasca Orde Baru, dimana kebebasan berekspresi semakin terbuka lebar namun tanggung jawab struktural lebih banyak berada di pundak individu (Sutopo, 2013). Selain itu, pemilihan komunitas 666 juga bertujuan untuk membangun kesejajaran konteks dengan perkembangan literatur mengenai studi budaya kaum muda serta metal ekstrem di beberapa negara lain, misalnya di Norwegia, Australia dan Italia (Hauge, 2011; Threadgold, 2018; Tarassi, 2018). Sementara dari sisi yang lain, komunitas 666 dipilih karena memiliki latar belakang kelas menengah. Hal ini dipandang sesuai dengan karakteristik praktik budaya kaum muda di Indonesia yang sejak era 1990-an lebih banyak berafiliasi dengan kelas menengah.

Proses pengumpulan data serta pemahaman atas kode-kode kultural yang tersemat pada interaksi di dalam skena metal ekstrem, terbantu dengan posisi peneliti sebagai critical insider (Hodkinson, 2002). Terkait hal ini, penulis pertama telah menjadi bagian dari skena 
metal ekstrem Yogyakarta selama kurang lebih satu dekade. Namun demikian, penulis tetap mengambil jarak pada saat melakukan proses interpretasi data, dengan merujuk pada kerangka teoritis yang digunakan. Sehingga hasil interpretasi data tidak serta merta mengikuti logika subjektif para informan penelitian.

\section{KERANGKA TEORI}

Secara teoritis, para musisi komunitas 666 tidak hanya akan diposisikan sebagai bagian dari skena metal ekstrem dengan praktik kultural yang spektakuler, namun juga sebagai bagian dari struktur masyarakat yang lebih luas dengan praktik kehidupan normal (mundane) di luar skena (Kahn-Harris, 2004), khususnya sebagai kaum muda yang mengalami proses transisi menuju fase kedewasaan. Untuk mengartikulasikan cara pandang tersebut, maka penelitian ini akan menggunakan perspektif budaya kaum muda dan perspektif transisi kaum muda. Kemudian terkait dengan persoalan sistem ide sebagai salah satu landasan bagi tindakan individu dan kelompok, akan digunakan dua konsep lain, yaitu ranah dan juga doxa.

\section{Perspektif Budaya Kaum Muda}

Dalam perspektif budaya kaum muda, upaya untuk memahami berbagai praktik kultural kaum muda awalnya dilakukan melalui pemaknaan kaum muda sebagai kategori sosial khusus dengan sistem ide khusus yang berbeda dari masyarakat umum. Cara pandang ini digunakan oleh para ilmuwan sosial dari CCCS Birmingham School dan diartikulasikan melalui konsep subkultur (Hall \& Jefferson, 1976). Dengan kata lain, kelompok-kelompok kaum muda seperti punker, biker, dan rocker, dimaknai sebagai bagian dari masyarakat, akan tetapi memiliki nilai dan norma tertentu yang berbeda, sehingga praktik kultural yang dilakukan juga berbeda.

Namun sejalan kemudian, konsep subkultur tersebut dikritik karena dinilai tidak lagi relevan dan tidak mampu menggambarkan realitas praktis kelompok budaya kaum muda secara akurat (Bennett, 2011). Hal ini kemudian disusul dengan munculnya beberapa kajian budaya kaum muda dengan pendekatan konseptual yang berbeda. Dalam studi-studi yang selanjutnya disebut sebagai studi pasca subkultur tersebut, salah satu konsep yang digunakan adalah skena.

Secara mendasar, skena dapat dipahami sebagai sebuah ruang kultural yang terdiri dari beberapa praktik musikal dan arah pergerakan yang berbeda (Straw, 1991). Melalui pemahaman tersebut, dapat dilihat bahwa skena bukan merupakan entitas yang tunggal, melainkan lebih menyerupai sebuah struktur yang terdiri atas keterhubungan antar unsur yang berbeda. Dengan adanya keragaman unsur tersebut, skena menjadi sebuah entitas yang bergerak secara dinamis, di antara logika transformasi dan reproduksi, di mana upaya untuk mempertahankan praktik-praktik kultural tertentu dalam sebuah skena, akan selalu berhadapan dengan upaya-upaya pembaruan praktik. Hal inilah yang kemudian menjadi pembeda konsep skena dengan konsep subkultur ala CCCS, yang tidak dapat digunakan untuk mengartikulasikan pluralitas dalam kelompok budaya kaum muda (Hall dan Jefferson, 1976). Selain itu, alih-alih menggunakan kelas sebagai basis pembentukan solidaritas kelompok, sebagaimana asumsi konsep subkultur CCCS, konsep skena menempatkan sensibilitas selera dan estetika sebagai landasan bagi pengelompokan individu (Bennett, 2011). Kemudian jika dibandingkan dengan beberapa konsep lain yang juga sering digunakan dalam studi budaya kaum muda pasca subkultur, seperti

lifestyle dan neo tribes, konsep skena memiliki keunggulan untuk membangun penjelasan objektif atas praktik musikal, mulai dari praktik konsumsi hingga produksi (Bennett, 2004). 
Dalam studi mengenai musik metal ekstrem, konsep skena sudah pernah digunakan oleh Kahn-Harris (2007) untuk memahami realitas di Israel, Swedia, dan Britania Raya. Dalam penelitian tersebut, skena digunakan untuk menggambarkan keterhubungan para pelaku metal ekstrem di berbagai level, mulai dari lokal hingga global. Kemudian selain diposisikan sebagai sebuah ruang bagi artikulasi musikal para pelaku, skena metal ekstrem, sesuai logika transformasi dan reproduksi, terdiri atas dua unsur kultural berbeda, yaitu unsur transgresivitas (transgressivity) dan normalitas (mundanity). Kedua unsur kultural inilah yang kemudian menjadi sumber produksi pengetahuan bagi praktik musikal yang dilakukan oleh para pelaku dalam skena metal ekstrem. Adapun unsur transgresivisme mendorong agen untuk berpikir dan bertindak secara individual, yang kemudian secara kolektif akan memunculkan produk berupa kebaruankebaruan dalam skena. Sementara sebaliknya, unsur normalisme, mendorong agen untuk bertindak sesuai dengan kebiasaan-kebiasaan yang sudah ada secara komunal, sehingga secara akumulatif cenderung akan menciptakan reproduksi praktik kultural di dalam skena.

Selain itu, konsep transgresivitas (transgressivity) dan normalitas (mundanity) juga dapat digunakan sebagai representasi atas dinamika relasi antara skena metal ekstrem dengan ranah lain yang melingkupi, seperti masyarakat umum dan negara (Kahn-Harris, 2007). Sebuah skena dikatakan transgresif apabila memiliki relasi yang bersifat konfliktual dengan masyarakat di sekitarnya, sementara sebaliknya, dikatakan normalis juga memiliki relasi yang selaras dan harmonis. Di satu sisi, relasi tersebut bisa jadi disebabkan oleh ketidakselarasan nilai dominan di dalam skena dengan nilai dominan yang berlaku dalam masyarakat. Sementara di sisi lain, relasi tersebut juga dapat menjadi produk dari praktik diskursif dari pemegang otoritas dalam masyarakat.
Adapun relevansi konsep skena bagi artikel ini, diasumsikan sebagai ruang yang melingkupi praktik bermusik para musisi komunitas 666. Di dalam ruang berupa skena inilah proses pembentukan pengetahuan praktis, serta praktik dan karier bermusik para musisi komunitas 666 terjadi. Dengan kata lain, karakteristik pengetahuan praktis, praktik dan karier bermusik para musisi komunitas 666 tidak eksis begitu saja sesuai dengan kehendak individual dari para musisi, namun cenderung mengikuti logika kultur transgresivitas dan normalitas yang muncul dalam level kolektif skena. Secara spesifik, konsep skena akan berkaitan dengan persoalan pemaknaan yang muncul di kalangan musisi komunitas 666 mengenai musik metal ekstrem.

\section{Perspektif Transisi Kaum Muda}

Sementara dalam perspektif transisi, kaum muda atau youth dipahami sebagai salah satu kategori atau kelompok sosial dalam masyarakat yang sedang mengalami proses secara bertahap menjadi 'orang dewasa' (Wyn \& White, 1997). Adapun salah satu kriteria untuk dapat dikatakan dewasa adalah ketika seseorang telah memiliki pekerjaan full time (Sutopo, 2013). Dengan kata lain, seseorang dikategorikan dewasa ketika telah mampu membangun perekonomian secara mandiri. Melalui cara pandang ini, dapat dipahami bahwa transisi kaum muda tidak hanya bertumpu pada kehendak dan kapasitas individual, namun juga berkaitan dan dipengaruhi oleh mekanisme sosial objektif yang melingkupi. Hal inilah yang menjadi penjelasan logis atas kompleksitas transisi kaum muda menuju fase dewasa, dimana narasi yang muncul bisa jadi tidak linier, tunggal dan sistematis. Misalnya, transisi yang dilalui oleh kaum muda dari kelas bawah, bisa jadi berbeda dengan kaum muda dari kelas menengah dan atas, karena kaum muda kelas bawah harus berhadapan dengan risiko kegagalan pendidikan dan diskriminasi institusional yang lebih besar, yang berpotensi mendorong kaum muda 
kelas bawah pada pengangguran. Kemudian contoh lain bisa dijumpai dari kaum muda dari wilayah rural yang harus bermigrasi ke ruang-ruang perkotaan untuk dapat membangun kemandirian ekonomi.

Proses menuju kemandirian ekonomi tersebut tidak hanya terkait dengan ranah ekonomi objektif secara an sich, namun juga terkait dengan aspek kultural. Sebagaimana dijelaskan dalam Sutopo (2011), bahwa pilihan pekerjaan dan karir, yang merupakan medium untuk membangun kemandirian ekonomi, mendapat pengaruh yang besar dari keluarga, khususnya orang tua. Hal ini setidaknya menjadi gambaran mengenai karakteristik transisi kaum muda di Indonesia yang tidak otonom. Karena itu penting kiranya untuk mempertimbangkan peran keluarga dalam pembahasan mengenai proses transisi kaum muda di Indonesia.

Terkait dengan perspektif transisi, dalam artikel ini para musisi komunitas 666 juga dipahami sebagai kaum muda dengan aspek kehidupan normal yang lumrah, yang juga dialami oleh kaum muda lainnya. Hal tersebut direpresentasikan melalui pergerakan sosial dari kelompok dependen menjadi independen secara ekonomi. Dalam proses tersebut, para musisi sebagai kaum muda perlu melalui beberapa domain, seperti ranah pendidikan dan pekerjaan. Kemudian dengan mempertimbangkan karakter transisi kaum muda di Indonesia yang relatif tidak otonom, maka fokus dari perspektif transisi akan diarahkan pada peran institusi keluarga sebagai domain lain yang juga fundamental dalam pergerakan sosial kaum muda menuju fase independensi. Hal ini khususnya terkait dengan persoalan konstruksi sosial mengenai pekerjaan yang muncul di kalangan para musisi komunitas 666.

Ranah \& Doxa

Konsep ranah merupakan produk dari cara pandang Bourdieu yang menilai bahwa kehidupan sosial masyarakat terdiri atas berbagai ruang berbeda, namun terhubung satu sama lain. Konsep ranah digunakan Bourdieu untuk menggambarkan ruang sosial yang membingkai berbagai praktik sosiokultural para agen, sekaligus sebagai kritik terhadap cara berpikir rasionalis yang menempatkan tindakan manusia sebagai sebuah produk dari kalkulasi rasional purposif individu. Di dalam ranah inilah terjadi relasi kontestatif antar agen, atau secara lebih spesifik dapat dijelaskan sebagai pertarungan antar agen untuk memperebutkan posisi sosial. Karena itu ranah dapat disebut sebagai field of struggle (arena pertarungan). Adapun kontestasi atau pertarungan tersebut dilandasi oleh adanya modal sebagai prasyarat untuk menempati suatu posisi sosial, serta distribusi modal yang tidak merata, sehingga relasi antar agen dalam ranah bersifat asimetris, dengan ditentukan oleh akumulasi modal yang dimiliki oleh masing-masing agen (Bourdieu \& Wacquant, 1992).

Ranah dapat dipahami sebagai kelanjutan dan kritik dari konsep struktur yang dikemukakan oleh Marx. Ranah dipahami sebagai kelanjutan dari struktur karena melalui konsep ini Bourdieu mengamini realitas objektif dan mekanisme simbolik yang mengatur relasi antar individu atau agen. Namun di sisi lain, ranah juga merupakan kritik dari konsep struktur, sebab meski terdapat relasi hirarkis antar ranah yang berbeda, masingmasing ranah dalam kehidupan sosial masyarakat memiliki aturan main yang relatif otonom. Dalam hal ini, aturan main tersebut menentukan bentuk modal (ekonomi, kultural, sosial, simbolik) yang berlaku dan memiliki nilai tinggi dalam suatu ranah, atau jika dijelaskan secara sederhana, dalam permainan yang berbeda akan terdapat kartu utama yang berbeda pula (Bourdieu and Wacquant, 1992).

Terkait hal ini, Bourdieu melihat bahwa tidak seluruh ranah memiliki aturan main yang selaras dengan karakteristik 
kehidupan sosial era kapitalistik. Karena itu Bourdieu membagi ranah dalam dua kategori, yakni ranah yang dibangun atas kepentingan ekonomi (field of interest) sebagaimana terepresentasikan oleh ranah bisnis dengan kepentingan keuntungan material ekonomi, serta ranah yang tidak dilandasi oleh kepentingan ekonomi (field of disinterestedness) sebagaimana terepresentasikan dalam ranah artistik dengan autentisitas kultural, dan ranah religi dengan pemahaman, kepatuhan, dan ketaatan beragama. Dengan kata lain, setiap ranah merupakan mikrokosmos dalam kehidupan sosial yang memiliki logika spesifik dan tidak dapat direduksi satu sama lain.

Kemudian selain disebut sebagai field of struggle, ranah juga disebut sebagai arena pertarungan 'kekuatan ideologis' (field of forces). Hal ini berkaitan dengan adanya 'pengetahuan yang diamini begitu saja' atau 'taken for granted knowledge' dalam setiap ranah. Lebih lanjut, doxa di dalam ranah tidak hanya berdiri sendiri melainkan hadir secara bersama dengan ortodoxa dan heterodoxa. Adapun relasi dari ketiga bentuk pengetahuan tersebut saling berkontestasi satu sama lain, mengikuti logika kerja ranah yang kontestatif. Selain itu, pengetahuan ini juga mengikuti kontur hirarki posisi antar agen di dalam ranah. Implikasinya, terdapat pengetahuan yang lebih dominan dari pengetahuan yang lain. Terkait hal ini, doxa melekat pada kuasa simbolik yang dimiliki agen dominan dalam suatu ranah. Kemudian keberadaan doxa di dalam ranah ini ditopang oleh ortodoxa, yakni pengetahuan taken for granted lain yang selaras dan memperkuat kelanggengan dominasi doxa dalam suatu ranah. Namun di sisi yang lain, terdapat heterodoxa sebagai pengetahuan taken for granted lain yang berlawanan dan 'mengganggu' dominasi doxa di dalam ranah (Bourdieu and Wacquant, 1992).

Pada artikel ini, konsep ranah dan doxa digunakan sebagai penghubung antara konsep skena dalam perspektif kaum muda, dengan keluarga dan proses transisi yang dialami kaum muda. Adapun masingmasing skena dan keluarga, sebagai ruang sosial bagi para musisi komunitas 666 (Kahn-Harris, 2007; Atkinson, 2014), memiliki 'pengetahuan yang diamini begitu saja' (doxic knowledge). Pengetahuanpengetahuan dari skena dan keluarga inilah yang kemudian terinternalisasikan dalam diri para musisi komunitas 666 sebagai agen, dan terkesternalisasikan melalui praktik atau tindakan. Melalui logika ini, maka dapat dipahami bahwa para musisi komunitas 666 juga berposisi sebagai penghubung antara skena dengan keluarga.

\section{Basis Objektif Karir Profesional-Amatir}

Berbicara mengenai awal karier bermusik, para musisi komunitas 666 mulai masuk dan menjadi bagian dalam skena metal ekstrem ketika masih menempuh pendidikan pada jenjang sekolah menengah. Terkait hal ini, data menunjukkan bahwa selera musik para informan terbentuk dalam konteks kemapanan budaya konsumsi musik populer barat (Wallach, 2008), khususnya musik rock alternatif, di kalangan kaum muda kelas menengah perkotaan Yogyakarta. Adapun kemapanan konsumsi musik rock alternatif barat tersebut, ditopang oleh habitus kolektif dalam ruang sosial antar siswa pada institusi pendidikan menengah kota Yogyakarta, serta eksistensi media massa (seperti MTV) dan agen distribusi artefak musik barat (seperti PT Indosemarsakti) sebagai cultural broker atau penghubung produsen dan konsumen budaya (Bennett dan Waksman, 2014).

Dalam hal ini, institusi pendidikan menengah tidak hanya berperan sebagai sumber akumulasi modal kultural (embodied dan institutionalized), namun juga sebagai arena kontestasi antar siswa. Predikat yang diperebutkan oleh mereka tidak hanya terbatas pada predikat 'siswa/i berprestasi' dan 'pintar' saja, namun juga berbagai predikat lain seperti 


'ganteng/cantik', 'modis', 'sangar
(jagoan)', dan juga 'keren'. Dihadapkan pada kondisi tersebut, konsumsi serta replikasi musik (melalui band) rock alternatif yang disediakan oleh media massa menjadi langkah strategis bagi para informan untuk untuk menjadi 'keren' di antara rekan sebaya (peer). Hal ini sebagaimana dijelaskan:

\begin{abstract}
"Kalau kamu tanya pengen main musik, dari SMP saya sudah pengen main musik. Tapi memang terbengkalai karena waktu itu saya main voli... Terus akhirnya saya masuk 4B (salah satu SMA di Yogyakarta)... Apa voli itu kampungan ya? Jujur waktu itu saya berpikir begitu... Saya sembunyikan itu, voli saya sembunyikan... Waktu itu saya merasa termarjinalkan. Saya merasa ibaratnya kemampuan yang saya bangun dari dulu saya jalan, lari jam 3 pagi dari rumah sampai pantai Samas itu kok sekarang tidak membuat saya bangga gitu lho. Akhirnya saya dapat momen, saya dapat beasiswa dari voli itu, saya izin sama orang tua, gimana kalau uang saya pakai untuk beli gitar. Nah saya pegang gitar, yasudah saya main musik. Zaman segitu kita hidup dari Tv lah, MTv lah. Yang saya lihat pasti Greenday, Blink 182, Sum 41, dan segala macem, masih seputaran MTv lah.” (Wawancara Ghoul, 2019)
\end{abstract}

Dalam tahap selanjutnya, perkembangan praktik bermusik musisi komunitas 666 menunjukkan kesesuaian dengan asumsi teoritis Bourdieu (1993) mengenai kecenderungan agen yang baru saja memasuki ranah untuk mempelajari dan mengikuti aturan main, serta berusaha untuk meningkatkan posisi sosial di dalam ranah. Hal tersebut terepresentasikan melalui bergabungnya para musisi informan pada komunitas-komunitas musik di Yogyakarta, jauh sebelum komunitas 666 terbentuk. Dalam komunitaskomunitas musik tersebut para informan mengakumulasikan modal-modal yang berlaku di dalam skena metal ekstrem, yakni referensi musik, jaringan dan rekognisi, serta kemampuan teknis bermusik (Sutopo \& Lukisworo, 2020).

\begin{abstract}
"Ya sepertinya rata-rata kita semua ini awalnya seperti itu deh, kalau tidak nongkrong, tidak bergabung ke komunitas ya tidak memperoleh kesempatan untuk tampil, tidak bisa mengenal orang lain." (Wawancara Ahmad, 2019)
\end{abstract}

Komitmen akumulasi modal inilah yang kemudian mendorong praktik para musisi komunitas untuk dapat melampaui amatirisme (Dummond, 1990; Quader, 2013). Bahkan proses akumulasi modal tersebut berlanjut hingga merambah skena musik underground lain di Yogyakarta, seperti skena hardcore-punk, serta skena metal ekstrem di wilayah geografis yang lain, baik dalam level nasional maupun global. Dengan kata lain, proses pembentukan karier bermusik para musisi komunitas 666 tidak hanya terjadi dalam satu skena saja. Adapun salah satu produk dari relasi yang dibangun dengan agen dari skena lain adalah kerjasama perilisan album dari para musisi komunitas 666 dengan label rekaman independen dari kota dan negara lain.

Karena itu dapat dipahami bahwa proses pembentukan awal karier bermusik para informan, alih-alih bermakna sebagai solusi atas alienasi sosial, sebagaimana hasil penelitian Rowe (2015), justru berkaitan dengan upaya untuk membangun distingsi simbolis. Narasi mengenai pembentukan awal karir bermusik para informan tidak menunjukkan adanya orientasi politik makro struktural, namun lebih berkaitan dengan kepentingan simbolis, dalam bentuk kebanggaan diri. Kemudian selain tidak dilandasi dengan alienasi sosial, proses pembentukan karier bermusik para musisi komunitas 666 ternyata juga tidak dilandasi dengan konflik generasional.

Hal ini terepresentasikan melalui signifikansi kontribusi keluarga terutama 
orang tua, dalam proses pembentukan karier bermusik para musisi komunitas 666 , yang saat membangun karier bermusik masih tergolong dependen. Adapun beberapa di antara kontribusi dari keluarga berbentuk dukungan secara langsung, seperti konsumsi rilisan fisik (CD dan kaset) serta alat musik. Sementara beberapa yang lain tersedia secara tidak langsung, misalnya dalam wujud uang jajan dan internet rumah yang dapat dikonversikan menjadi modal kultural yang berlaku dalam skena.

\footnotetext{
"Dulu saya pernah dibelikan ibu saya snare dan double pedal, kelasnya lumayan buat saya yang masih belajar dulu, walaupun habis itu saya jual terus ganti lagi, hahaha." (wawancara Rahadian, 2019)
}

Ketiadaan konflik generasional berimplikasi pada besarnya pengaruh keluarga terhadap kehidupan informan. Dalam hal ini, keluarga para musisi komunitas 666 yang tergolong kelas menengah, memiliki kecenderungan sama dengan umumnya keluarga kelas menengah di Indonesia, yakni berusaha untuk menyediakan fasilitas pendidikan formal dan mendorong kaum muda untuk mencapai pendidikan hingga level pendidikan tinggi, guna memenuhi kepentingan reproduksi posisi sosial (Sutopo, 2016). Karena itu karier bermusik tidak diposisikan sebagai amunisi bagi para musisi komunitas 666 dalam menghadapi transisi menuju ranah pekerjaan. Hal ini sebagaimana disampaikan oleh $\mathrm{S}$ sebagai salah satu orang tua dari musisi komunitas 666.

\footnotetext{
“... Ya kita sebagai orang tua itu kan bisanya ngasih sangu ke anak itu ya pendidikan mas. Saya pikir orang tuanya mas juga mikir gitu. Harapannya bisa dipakai besokbesok, kalau bandha (harta) bisa habis mas... " (Wawancara S, 2019)
}

Dengan demikian, dapat dipahami bahwa ketiadaan konflik generasional, berimplikasi pada keteriringan proses pembentukan karier bermusik di dalam skena dengan proses akumulasi modal kultural institutionalized. Hal inilah yang memberikan peluang memadai kepada para musisi komunitas 666 untuk membangun karier pekerjaan secara full time dalam berbagai bidang yang berbeda, sebagaimana terepresentasikan melalui pilihan pekerjaan para musisi komunitas 666. Implikasinya, karier bermusik para musisi komunitas 666 lebih mengarah pada karakteristik profesional-amatir, dimana motivasi ekonomi absen dari berbagai praktik kultural para musisi komunitas 666 di dalam skena metal ekstrem.

\section{Musik Metal Ekstrem sebagai Produk Budaya Transgresif}

Seiring dengan perkembangan keterlibatan para informan di dalam skena, terjadi perkembangan pengetahuan spesifik yang berlaku di dalam skena, yang salah satunya menyangkut pemahaman atau pemaknaan mengenai metal ekstrem. Lebih lanjut, terkait pemahaman mengenai metal ekstrem, yang dalam penelitian ini diposisikan sebagai salah satu landasan bagi permisahan karier bermusik dan pekerjaan, meski tampak beragam, namun para musisi komunitas 666 memiliki cara pandang yang relatif berada dalam satu koridor, yakni transgresivisme (KahnHarris, 2007). Hal ini direpresentasikan melalui pendapat dari beberapa musisi komunitas 666 mengenai metal ekstrem sebagai produk budaya yang harus diperlakukan dengan 'cara khusus', dan berbeda dengan produk budaya populer lain. Adapun 'cara khusus' ini perlu dimanifestasikan, salah satunya, dalam proses produksi dan distribusi musik. Hal ini sebagaimana terepresentasikan dalam kutipan wawancara berikut:

\footnotetext{
"Sejak kapan metal tidak elitis? Kamu harus tahu ini-itu, percuma kalau terus ditawarkan ke orang yang enggak paham... Makanya harus mau cari lah bro, kira-kira label mana yang benerbener peduli sama musik ini, yang
} 
sama-sama die hard. Tanya juga soal jaringannya, kira-kira dengan jaringan itu, bisa enggak menghubungkan kita ke orang-orang yang 'tepat', yang sama-sama die hard (penggemar berat)." (Wawancara Ghoul, 2019)

Dalam kutipan wawancara tersebut, perlakuan khusus terhadap musik metal ekstrem mengacu pada proses produksi musik dengan landasan pemahaman latar belakang sosio-historis mengenai metal ekstrem, yakni sebagai musik yang identik dengan berbagai bentuk transgresi atas normalitas kehidupan masyarakat (KahnHarris, 2007). Dalam hal ini, pemahaman tersebut dinilai mutlak diperlukan untuk dapat menghasilkan musik yang substantif dan berkualitas, yakni musik yang di dalamnya tersemat kode-kode transgresivitas. Pemahaman atas latar belakang sosio-historis metal ekstrem tersebut, diposisikan sebagai batas pemisah antara yang 'die hard'-pelaku dengan komitmen tinggi, yang dibuktikan dengan pemahaman mendalam- dengan 'yang lain'. Karena pemahaman tersebut untuk menjaga transgresivitas metal ekstrem, diperlukan proses distribusi melalui label rekaman dengan dimensi ide atau pemahaman yang serupa.

Kemudian selain proses distribusi album rekaman, perlakuan khusus juga perlu diwujudkan dalam praktik distribusi musik melalui pertunjukan langsung (live performance). Hal ini sebagaimana dijelaskan

"Ya kalau saya enggak terlalu kaku sih soal panggung, tapi ya minimal musik itu harus jadi yang utama. Kalau seperti acara clothing itu kan cuma jadi hiburan sampingan. Udah yang nonton belum tentu paham, pun belum tentu memperhatikan, jadi ya percuma kalau menurut saya, seperti enggak ada maknanya musik kita. Makanya kalau seperti kita ini diminta profesional, saya pikir agak sulit. Contoh saja seperti A dulu, dia punya kesempatan mencoba, tapi akhirnya malas juga kan, karena enggak mendapatkan apa yang

diharapkan." (Wawancara Ahmad, 2019)

Bahkan selain itu, beberapa informan lain melihat bahwa metal ekstrem merupakan musik yang perlu ditopang dengan independensi musisi sebagai produsen kultural. Hal ini sebagaimana dijelaskan:
"Kalau menurut saya yang penting dalam musik ini tu attitude sih, konsisten gitu... Ya kita kan memulai ini dengan senang-senang, jadi enggak asik aja sih kalau melakukan apa yang kita senangi tapi dengan batasan-batasan. Misalnya mau main, produksi, atau apa, harus mengikuti kata orang lain, kan enggak enak itu." (Wawancara Johan, 2019)

Adapun kata kunci berupa 'perlakuan khusus' serta independensi inilah yang merepresentasikan transgresivitas cara pandang para musisi komunitas 666. Melalui praktik tersebut, para musisi komunitas 666 berusaha menempatkan diri dalam posisi berseberangan dengan 'yang normal', atau dalam hal ini para pelaku dalam skena metal ekstrem dengan prinsip profesional-industrialistik (Lukisworo \& Sutopo, 2017), yang dinilai mengabaikan substansi metal ekstrem berupa nilai-nilai transgresivitas. Kemudian ketika transgresivitas ini dihubungkan dengan persoalan kebanggaan diri sebagai landasan bagi para informan untuk masuk dan terlibat dalam skena metal ekstrem, maka mengonversikan musik menjadi pekerjaan dapat dipahami sebagai sebuah tindakan penegasian terhadap kebanggaan para musisi komunitas 666 itu sendiri. Hal inilah yang menjadi dasar bagi kemunculan konsekuensi logis, berupa karakteristik karier bermusik para musisi komunitas 666 yang cenderung tidak cair, sehingga konversi musik sebagai tumpuan pemenuhan kebutuhan ekonomi, menjadi praktik yang tidak terpikirkan.

Peneliti : Pernah terpikirkan

$\begin{array}{rr}\text { untuk menjadi } \\ \text { musik }\end{array}$




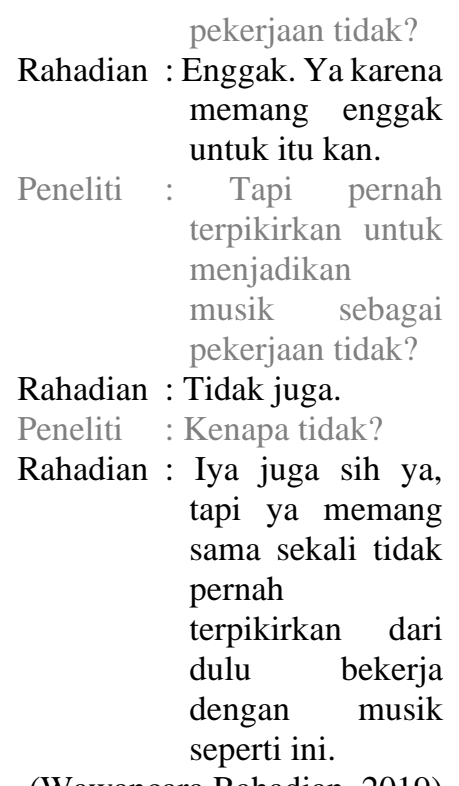

(Wawancara Rahadian, 2019)

Dengan kata lain, pemisahan antara musik dengan pekerjaan menjadi strategi para musisi komunitas 666 untuk mempertahankan kebanggaan diri dalam skena metal ekstrem, serta menjaga metal ekstrem agar tetap berada dalam koridor yang 'tepat', yakni sebagai produk budaya yang transgresif. Adapun cara pandang tersebut bukan merupakan suatu hal yang muncul begitu saja, melainkan dipelajari dan terbentuk seiring dengan dialog antara para musisi komunitas 666 dengan berbagai institusi dalam skena metal ekstrem sepanjang perjalanan karier bermusik mereka. Kemudian dengan pertimbangan karakteristik skena metal ekstrem Yogyakarta yang cenderung normalis, maka proses pembentukan pemahaman transgresivistik ini lebih berkaitan dengan relasi yang dibentuk oleh para musisi komunitas 666 dengan para pelaku skena musik underground lain di Yogyakarta, serta pelaku metal ekstrem di kota dan negara lain. Adapun hal ini dipertegas oleh kutipan wawancara berikut:

\footnotetext{
"Ya dari pengalaman bermusik ini saya jadi percaya kalau knowledge is power, betul itu. Harus banyak cari tahu dan ngobrol sama orang lain. Lagipula sekarang ada internet, jadi lebih mudah. Tinggal kita mau atau enggak sih kalau menurut saya." (Wawancara Ghoul, 2019)
}

Dengan kata lain, meski praktik profesional-amatir para musisi komunitas 666 bersifat reproduktif, perulangan dari yang sudah ada sebelumnya, namun praktik ini dilandasi oleh aspek kultural. Berbeda dengan profesional-amatir agen-agen dominan dalam skena metal ekstrem Yogyakarta yang lebih dilandasi oleh aspek struktural. Karena itu dalam konteks skena metal ekstrem Yogyakarta, cara pandang para musisi komunitas 666 ini dapat dipahami sebagai sebuah heterodoxa (Bourdieu, 2000). Namun berdasarkan pengamatan di lapangan, cara pandang ini hanya berkembang di lingkungan sosial komunitas 666 saja, alih-alih disebarkan di dalam skena. Dengan kata lain, tidak terdapat upaya dari para musisi komunitas 666 untuk menggeser doxa atau wacana dominan yang berkembang di dalam skena metal ekstrem Yogyakarta yang bercorak normalistik.

\section{Pekerjaan sebagai Medium Reproduksi Kelas}

Kemudian terkait dengan pekerjaan, sebagai alasan lain yang melandasi pemisahan antara musik dan pekerjaan, peneliti melihat bahwa makna yang muncul di kalangan informan terkait erat dengan posisi sosial para informan sebagai kelas menengah. Dalam hal ini, pekerjaan tidak hanya dipahami oleh para informan sebagai medium untuk membangun kemandirian ekonomi, namun juga sebagai medium untuk mencapai -minimal - standar kehidupan saat ini. Dengan adanya pertimbangan tersebut maka diperlukan 'pekerjaan layak' yang dapat menunjang upaya pemenuhan standar hidup sesuai dengan yang 'dialami' oleh para informan saat ini. Bahkan bagi sebagian musisi komunitas 666, melampaui pencapaian orang tua, dalam konteks pekerjaan, menjadi salah satu pertimbangan dalam memilih pekerjaan. Karena itu, menjadi musisi metal ekstrem profesional bukan merupakan pilihan yang tepat, sehingga harus ternegasikan dari pilihan pekerjaan. 
Lebih lanjut, bagi sebagian musisi komunitas 666, keputusan untuk tidak menjadikan musik sebagai pekerjaan dan memilih pekerjaan full-time non musisi sudah direncanakan sejak jauh hari. Hal ini sebagaimana terepresentasikan dalam pendapat Putra yang saat ini berprofesi sebagai aparatur sipil negara dalam sebuah institusi negara di Jakarta.

\begin{abstract}
"Ya saya memang ingin masuk dalam ranah pekerjaan ini. Maka dari itu saya sampai di Jakarta... Dulu bapak saya (pensiunan ASN Daerah di DIY) pernah bilang kalau daftar di Jogja saja tidak apa-apa, tapi menurut saya tanggung, saya masih muda, jenjang saya masih panjang. Kalau ingin membangun karir menurut saya mending di pusat sekalian." (Wawancara Putra, 2019)
\end{abstract}

Meskipun terdapat sebagian informan yang sempat mengalami perubahan pilihan pekerjaan, pertimbangan yang pada akhirnya melandasi perubahan pilihan tersebut juga bertumpu pada persoalan yang sama, yakni pendapatan serta kemapanan ekonomi. Hal ini sebagaimana dijelaskan:

\begin{abstract}
"Kalau menurut saya tidak bisa mencukupi sih... Enggak aneh-aneh deh, buat nikah, membangun keluarga, beli rumah, kendaraan, standar kan. Buat itu saja menurut saya belum bisa mencukupi. Pun jika memang ingin hidup dari bermusik, semestinya dibangun sejak awal. Jadi sudah niat. Karena bikin band supaya bisa laku itu sulit lho. Lagi pula jadi tidak asih sih, kita kan rata-rata ingin senang-senang di sini. Jadi ya kalau saya sih musik tetap hobi saja, pekerjaan saya ya saya kerja di kantor." (Wawancara Ahmad, 2019)
\end{abstract}

Kemudian sebagaimana yang terjadi pada proses pembentukan makna musik metal ekstrem, makna pekerjaan ini juga tidak muncul begitu saja. Dalam hal ini, terdapat dua hal yang patut dipertimbangkan, yakni mengenai ketiadaan konflik generasional antara para informan dengan keluarga, sebagaimana dijelaskan pada bagian sebelumnya, serta mengenai dominasi orang tua dalam proses pemilihan karier bagi kaum muda (Sutopo, 2011; 2016). Dengan mempertimbangkan kedua hal tersebut, maka dapat dipahami bahwa penilaian atas kelayakan pekerjaan, merupakan konstruk berpikir yang diturunkan dari orang tua. Hal ini tampak secara eksplisit dalam kutipan wawancara berikut:

"Ya saya punya (latar belakang S1)
Sastra Inggris, itu yang mengubah
hidup saya. Lagipula kuliah lama dan
keluar biaya banyak. Jadi saya pikir
saya harus bisa memaksimalkan itu
lah, paling enggak kerja di tempat
yang berhubungan dengan bidang
kuliah saya sih... Ya dulu sebenarnya
saya pernah kepikiran mau serius
profesional (bermusik) sih, tapi
almarhum (bapak) pernah ngomong,
ngikut saja nak, tapi katanya kamu
senang sastra Inggris nak? Ya habis
itu saya memutuskan (mencari kerja)
menggunakan sastra (ijazah
pendidikan)." (Wawancara Ghoul,
2019)

Berdasarkan paparan tersebut, terdapat dua hal yang menarik untuk dicatat. Pertama terkait dengan latar belakang kelas menengah para musisi komunitas 666 serta pertimbangan atas kehidupan saat ini sebagai standar minimal dalam pemilihan pekerjaan, yang merepresentasikan upaya dari para musisi komunitas 666 untuk menghindari 'penurunan kelas sosial'. Hal ini selaras dengan karakteristik kelas menengah baru yang cenderung enggan disamakan dengan kelas bawah (Gerke, 2000). Cara pandang inilah yang kemudian menyebabkan kondisi objektif skena terlihat tidak 'menjanjikan' dan karier bermusik tampak tidak layak untuk dijadikan sebagai pekerjaan. Kemudian yang kedua terkait dengan keterlibatan orang tua dalam proses pemilihan pekerjaan, yang merepresentasikan keselarasan transisi para musisi komunitas 666 dengan karakteristik transisi kaum muda yang bersifat konvensional atau non liberal, dimana keluarga memiliki andil 
besar dalam proses pemilihan pekerjaan. Melalui kedua hal tersebut, dapat dipahami bahwa keputusan pemilihan pekerjaan sebagai salah satu aspek yang berpengaruh terhadap pemisahan karir bermusik dengan pekerjaan, dipengaruhi oleh cara pandang kelas menengah yang diinternalisasikan oleh para musisi komunitas 666 melalui keluarga. Lebih lanjut, dapat dipahami pula bahwa pemilihan pekerjaan full time non musisi menjadi strategi bagi para musisi komunitas 666 untuk mempertahankan atau mereproduksi posisi sosial dalam struktur masyarakat dalam konteks Indonesia.

\section{PENUTUP}

Praktik pemisahan antara karir bermusik dan pekerjaan merupakan strategi untuk mempertahankan kebanggaan transgresif di dalam skena metal ekstrem serta reproduksi posisi sosial di dalam tatanan masyarakat Indonesia (gengsi kelas/distingsi simbolis). Di satu sisi, pemisahan antara musik dan pekerjaan tersebut dilandasi oleh pemahaman para informan mengenai metal ekstrem sebagai sebuah produk budaya yang transgresif, sehingga harus diperlakukan dengan 'cara khusus' dan harus ditopang dengan independensi musisi. Karena itu karakteristik praktik para informan menjadi cenderung tidak cair, dan bahkan bagi sebagian informan, konversi musik sebagai pekerjaan merupakan suatu hal yang tidak pernah terpikirkan. Lebih lanjut, pemahaman ini tidak muncul begitu saja, namun terbentuk secara dialektis mengikuti dialog antara para informan dengan berbagai institusi dalam skena metal ekstrem. Di sisi yang lain, praktik permisahan karier bermusik dan pekerjaan tersebut juga dilandasi oleh pemahaman para informan mengenai pekerjaan sebagai sebuah medium reproduksi kelas. Melalui pemahaman ini, metal ekstrem menjadi tergolong tidak layak untuk disebut sebagai pekerjaan dan harus ternegasikan dari sekian pilihan pekerjaan yang mungkin untuk dipilih para informan. Adapun pemahaman mengenai pekerjaan tersebut, berkaitan dengan latar belakang para informan sebagai bagian dari kelas menengah di Indonesia, dimana keluarga, khususnya para orang tua, memiliki kontribusi besar dalam kehidupan kaum muda. Dengan kata lain, pemahaman ala kelas menengah mengenai pekerjaan tersebut diinternalisasikan oleh para informan melalui medium orang tua. 
DAFTAR PUSTAKA

Atkinson, Will. (2014). A Sketch of 'family' as field: From realized category to space of struggle. Acta Sociologica, Vol. 57 (3): 223-235.

Baulch, Emma. (2003). Gesturing Elsewhere: The Identity Politics of Balinese Death/Thrash Metal Scene. Popular Music, Vol. 22, No. 2, Hal. 195-215.

Bennett, Andy \& Steve Waksman. (2014). The SAGE Handbook of Popular Music. California: Sage Publication.

Bennett, Andy. (2002). Researching youth culture and popular music: a methodological critique. British Journal of Sociology Vol. No. 53, Issue No. 3 (September 2002), Hal. 451-466.

Bennett, Andy. (2003). The Use of 'Insider' Knowledge in Ethnographic Research on Contemporary Youth Music Scenes. Dalam Andy Bennett, Mark Cieslik, \& Steven Miles (Ed.), Researching Youth (Hal. 186-199). Hampshire: Palgrave Macmillan.

Bennett, Andy. (2011). The PostSubcultural Turn: Some Reflections 10 years on. Journal of Youth Studies, 14:5, 493-506.

Bennett, Andy. (2018). Youth, Music and DIY Careers: A Critical Overview. Cultural Sociology 2018, Vol. 12 (2), 133-139.

Bourdieu, Pierre \& Loic Wacquant. (1992). An Invitation to Reflexive Sociology. Chicago: University of Chicago Press.

Bourdieu, Pierre. (1993). The Field of Cultural Production. New York City: Columbia University Press.

Bourdieu, Pierre. (2000). Pascalian Meditations. Stanford: Stanford University Press.
Dummond, John D. (1990). The Characteristics of Amateur and Professional. International Journal of Music Education, 1990, Vol. 15, Hal. 3-8.

Gerke, Solvay. (2000). Global Lifestyle under Local Conditions: the New Indonesian Middle Class. Dalam Chua Beng-Huat (Ed.), Consumption in Asia: Lifestyle and Identities (Hal. 135-158). London: Routledge.

Hall, Stuart \& Tony Jefferson (Eds.). (1976). Resistance Through Rituals: Youth subcultures in post-war Britain. London: Routledge.

Hauge, Elisabeth Sorfjorddal. (2011). How Do Metal Musicians Become Entrepreneurial? A Phenomenological Investigation on Opportunity Recognition (Disertasi Doktoral). BI Norwegian Business School.

Hebdige, Dick. (1979). Subculture: The Meaning of Style. London: Routledge.

Hodkinson, Paul. (2002). Goth: Identity, Style and Subculture. Oxford: Berg.

James, Kieran \& Rex John Walsch. (2018). Islamic Religion and Death Metal Music in Indonesia. Journal of Popular Music Studies, Vol. 30, No. 3, Hal. 129-152.

Kahn-Harris, Keith. (2004). Unspectacular Youth Culture? Transgression and Mundanity in the Global Extreme Metal Scene. Dalam Bennett, Andy \& Keith Kahn-Harris (eds), After Subculture: Critial Studies in Contemporary Youth Culture (Hal. 107-118). London: Palgrave Macmillan.

Kahn-Harris, Keith. (2007). Extreme Metal Music and Culture on the Edge. Oxford: Berg. 
Lukisworo, Agustinus Aryo \& Oki Rahadianto Sutopo. (2017). Metal DIY: Dominasi, Strategi, dan Resistensi. Jurnal Studi Pemuda, Vol $6(2), 578-589$.

Martin-Iverson, Sean. (2011). The Politics of Cultural Production in the DIY Hardcore Scene in Bandung, Indonesia (Disertasi Doktoral). University of Western Australia, Australia.

Muggleton, David. (2000). Inside Subculture: Postmodern Meaning of Style. Oxford: Berg.

Rowe, Paula. (2015). Becoming and Being Metalhead: Exploring the significance of heavy metal music and culture for youth identities and aspiration biographies (Disertasi Doktoral). University of South Australia, Australia.

Straw, Will. (1991). Systems of articulation, logics of change: Communities and scenes in popular music. Cultural Studies, 5:3, 368388.

Sutopo, Oki Rahadianto \& Agustinus Aryo Lukisworo. (2020). Praktik Bermusik Musisi Muda dalam Skena Metal Ekstrem. Jurnal Sosiologi Pendidikan Humanis, Vol. 5 (2), 107119.

Sutopo, Oki Rahadianto \& Pam Nilan. (2018). The Constrained Position of Young Musicians in the Yogyakarta Jazz Community. Asian Music, Volume 49, Number 1, Winter/Spring 2018, Hal. 34-57.

Sutopo, Oki Rahadianto, Gregorius Ragil Wibawanto \& Agustinus Aryo Lukisworo. (2020). Melampaui Subkultur/Post-Subkultur: Musisi sebagai Jalan Hidup Kaum Muda.
Jurnal Studi Pemuda. Volume 9, No. 1, Tahun 2020, Hal. 1-12.

Sutopo, Oki Rahadianto. (2011). Masih Ada Alternatif Lain: Musisi Jazz sebagai Jalan Hidup Pemuda. Dalam M. Najib Azca, Subando Agus Margono \& Lalu Wildan (Ed.), Pemuda Pasca Orba: Potret Kontemporer Pemuda Indonesia (Hal. 217-232). Yogyakarta: YouSure UGM.

Sutopo, Oki Rahadianto. (2013). Hidup adalah Perjuangan: Strategi Pemuda Yogyakarta dalam Transisi dari Dunia Pendidikan ke Dunia Pekerjaan. Jurnal Sosiologi MASYARAKAT, Vol. 18, No. 2, 161179.

Sutopo, Oki Rahadianto. (2016). Young Indonesian Musician: Making the Transition to Adulthood through Entrepreneurial Activities and Mobility (Disertasi Doktoral). University of Newcastle, Australia.

Tarassi, Silvia. (2018). Multi-Tasking and Making Living from Music: Investigating Music Careers in the Independent Music Scene of Milan. Cultural Sociology 2018, Vol. 12 (2), 208-223.

Threadgold, Steven. (2018). Creativity, Precarity, and Illusio: DIY Cultures and 'Choosing Poverty'. Cultural Sociology 2018, Vol. 12(2), 156-173.

Wallach, Jeremy \& Alexandra Levine. (2011). 'I want you to support local metal': A theory of metal formation. Popular Music History, 6.1/6.2, 116134.

Wallach, Jeremy. (2005). Underground Rock Music and Democratization in Indonesia. World Literature Today, Vol. 79, No. 3/4, USA.

Wallach, Jeremy. (2008). Modern Noise, Fluid Genres: Popular Music in 
Indonesia 1997-2001. Wisconsin:

The University of Wisconsin Press.

Wyn, Johanna \& Rob White. (1997).

Rethinking Youth. Crows Nest: Allen

\& Unwin. 